\title{
Wheat blast disease: danger on the move
}

\author{
Christian D. Cruz ${ }^{1} \cdot$ Barbara Valent ${ }^{1}$ (B)
}

Received: 13 March 2017 / Accepted: 3 May 2017 / Published online: 31 May 2017

(C) The Author(s) 2017. This article is an open access publication

\begin{abstract}
Wheat blast is caused by the fungus Magnaporthe oryzae Triticum pathotype (MoT). The potential for wheat blast to cause widespread losses demands immediate action to understand and manage this explosive disease. The recent appearance of wheat blast in Bangladesh demonstrates the threat of global spread, which could occur via the movement of infected seed or grain. MoT mainly infects wheat heads, with symptoms closely resembling Fusarium head blight. To date, wheat blast is considered an intractable and dangerous disease and fungicides have shown limited efficacy. Disease management requires identification of new resistance sources and a complete understanding of MoT ecology and wheat blast epidemiology. Understanding the full potential for pathogen variability, including any role for sexual reproduction in the field, is critical. A small number of pathogen avirulence $(A V R)$ genes block other host-adapted M. oryzae pathotypes from infecting wheat; so potential $A V R$ gene mutations leading to new host jumps remain a threat. Indeed, some strains of the closely related Lolium pathotype, causing gray leaf spot of turf grasses, already infect wheat. This review provides the current status of wheat blast research and disease control strategies indicating similarities and differences to rice blast and gray leaf spot. Critical knowledge gaps are discussed.
\end{abstract}

Keywords Magnaporthe oryzae $\cdot$ Pyricularia $\cdot$ Triticum aestivum · Wheatblast · Brusone · Gray leaf spot · Host species specificity $\cdot$ Host jump

Section Editor: Emerson M. Del Ponte

Barbara Valent

bvalent@ksu.edu

1 Department of Plant Pathology, Kansas State University, 1712 Claflin Rd./4024 Throckmorton PSC, Manhattan, KS 66506, USA

\section{Emergence and spread of wheat blast}

Wheat blast, or 'brusone', is caused by the haploid, filamentous, ascomyceteous fungus Magnaporthe oryzae (Catt.) B.C. Couch 2002 (synonym to Pyricularia oryzae Cavara 1892) (Couch and Kohn 2002; Zhang et al. 2016a). Blast has emerged as an explosive threat to wheat production that can cause up to $100 \%$ yield losses under the right environmental conditions (Fig. 1a). Wheat blast is caused by a subpopulation within M. oryzae, the M. oryzae Triticum pathotype (MoT) that is distinct from subpopulations infecting rice (the Oryza pathotype, $\mathrm{MoO}$ ); finger millet (the Eleusine pathotype); Italian or foxtail millet (the Setaria pathotype); and turf grasses (the Lolium pathotype, MoL); among others. Wheat blast was observed for the first time in 1985 in the Brazilian state of Paraná, where commercial wheat fields in six municipalities were severely affected (Igarashi et al. 1986; Maciel 2011). By 1986, the disease had spread to northern and western Paraná, northwestern São Paulo State, and southern Mato Grosso do Sul. Soon after, blast was detected in other important wheatproducing regions of Brazil (Goulart et al. 1990; Igarashi 1990; Picinini and Fernandes 1990; Dos Anjos et al. 1996; Goulart and Paiva 2000). In 1996, blast was reported for the first time outside of Brazil, in Bolivia's most important region for wheat production, the Santa Cruz Department (Barea and Toledo 1996). Wheat blast reached Itapúa and Alto Paraná Departments of Paraguay in 2002 (Viedma 2005), and the province of Formosa in northeastern Argentina in 2007 (Cabrera and Gutiérrez 2007). In 2012, blast was detected in an experimental station within the Buenos Aires Province, potentially threatening important wheat production areas of Argentina (Perello et al. 2015). In 2016, a wheat blast outbreak was reported for the first time outside of South America, in Bangladesh's districts of Kushtia, Meherpur, Chuadanga, Jhenaidah, Jessore, Barisal, Bhola, Magura, Narail, and 

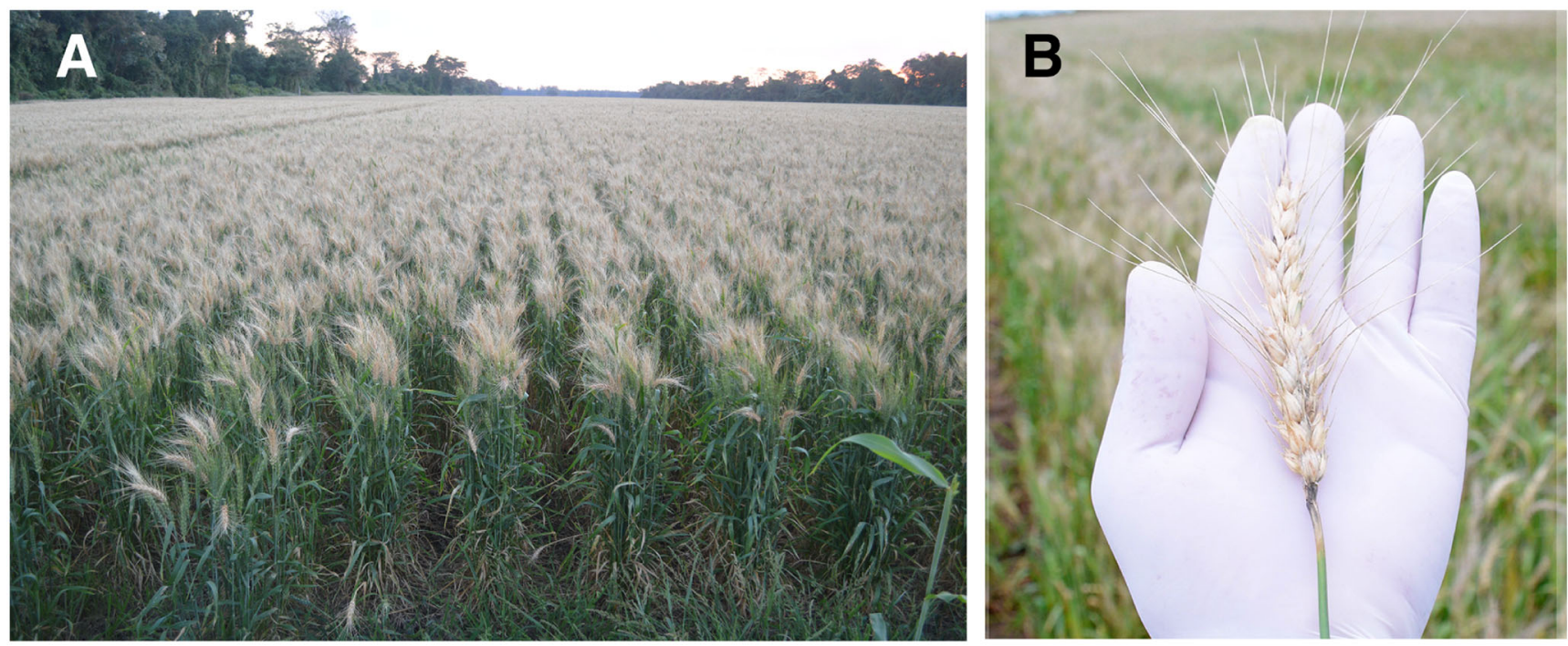

Fig. 1 Total bleaching of heads in a susceptible wheat cultivar. a Commercial wheat field near Santa Cruz, Bolivia, showing 100\% loss to wheat blast. b Close up view of a bleaching symptoms resulting from

Faridpur (Malaker et al. 2016). This first incidence of wheat blast affected approximately $15 \%$ of Bangladesh's total wheat area. Comparative genome analyses showed that fungal isolates from diverse wheat regions in Bangladesh appeared clonal and were closely related to highly aggressive MoT isolates from South America (Farman et al. 2017; Malaker et al. 2016). An independent pathogenomics analysis confirmed that the Bangladeshi wheat blast fungus was most likely moved in from South America (Islam et al. 2016). This large-scale incidence of wheat blast outside South America has underscored a concern about the potential spread of blast to other wheat producing areas in Bangladesh, South Asia and beyond.

In addition to the recent emergence of wheat blast, gray leaf spot (GLS), a serious disease on turf grasses used in the golf course industry, emerged in 1991 in Pennsylvania and subsequently spread across the U.S. Magnaporthe oryzae isolates causing GLS on perennial ryegrass (Lolium perenne), annual ryegrass (Lolium multiflorum) and tall fescue (Festuca arundinacea) constitute the distinct Lolium pathotype (MoL) (Viji et al. 2001; Farman 2002; Uddin et al. 2003b; Tosa et al. 2004). This disease also occurs in Japan, presumably introduced through movement of perennial ryegrass seed from the U.S. (Tosa et al. 2004; Tosa et al. 2016). In the U.S. in 2011, M. oryzae was isolated from a single diseased wheat spike in a University of Kentucky wheat trial plot in Princeton, Kentucky. The M. orzyae 'Kentucky' isolate appears to be a native U.S. MoL strain based on comparative analyses that showed its genome sequence was more similar to native MoL strains than to South American MoT strains (Farman et al. 2017). Subsequent scouting failed to identify a second occurrence on wheat in the U.S. However, this fortuitous finding highlighted the close relationship between the MoT and MoL populations (Viji et al. 2001; Farman 2002; Tosa et al. an infection point at the base of the rachis. Both pictures were taken at the milk-to-dough wheat development stage. However, partial death of the wheat spike can also occur at earlier stages

2004; Farman et al. 2017), and led to the understanding that native $\mathrm{MoL}$ isolates also pose a risk to U.S. wheat production. That is, a subset of U.S. MoL isolates already infect wheat, although they are less aggressive on wheat than MoT strains from the 1980's in Brazil (Viji et al. 2001; Farman et al. 2017). The origins of the wheat blast and GLS populations are unknown, although, it has been suggested that 'host jumps' may account for their recent emergence in Brazil and the U.S. (Tosa et al. 2007; Tosa et al. 2016). The growing intensities of wheat blast and GLS highlight the importance of understanding past host jumps, and of determining the potential for new potentially pandemic strains to occur on additional crops.

\section{Symptoms and losses}

Wheat blast is considered a major disease affecting wheat production. The economic importance of this disease derives from the fact that the fungus can reduce yield and grain quality (Goulart et al. 2007). Grains from blast-infected spikes from highly susceptible cultivars are often small, shriveled and deformed, with low test weight (Goulart et al. 2007). These grains are often discarded during the post harvest process of threshing or winnowing (Urashima et al. 2009). Highest yield losses occur when spike infections begin during flowering or early grain formation (Goulart et al. 2007). Yield losses up to $100 \%$ are reported for susceptible cultivars (Goulart and Paiva 1992, 2000). Fusarium head blight, which has similar spike symptoms, impacts wheat production around the world (McMullen et al. 1997).

The most visible symptom of wheat blast in the field is bleaching of the spike (Fig. 1a). An infection in the rachis or peduncle can block the translocation of photosynthates and 
Fig. 2 Wheat blast lesions on spikes, leaves and stems. Partial (a) or total (b) spike sterility depends on susceptibility of cultivar, time, and point of infection. (c) Gray sporulating lesions on an upper, younger leaf showing distinct yellow chlorotic halos. (d) Gray sporulating lesions on lower canopy senescent leaves. (e) Lesions on stems show pale tan centers with brown margins after sporulation has finished
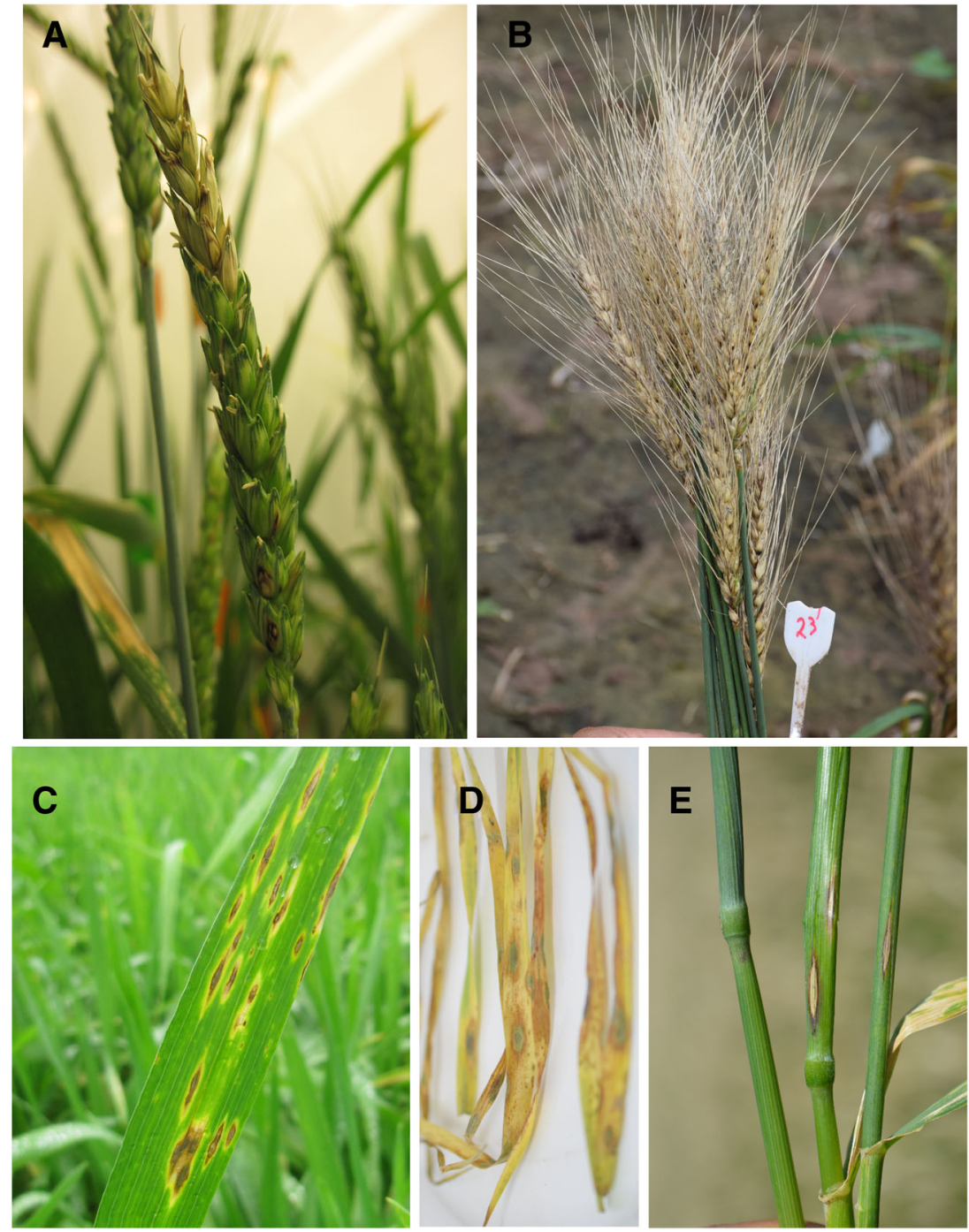

kill the upper parts of the spike (Fig. 1b). As a consequence, partial or total spike sterility can occur depending on susceptibility of cultivar, timing, and point of infection (Fig. 2a-b). Infected awns show brown to whitish discoloration while infected glumes show elliptical lesions with reddish-brown to dark-gray margins. Lesions have grey centers during sporulation and white to tan centers after spore release (Igarashi et al. 1986; Igarashi 1990). Grain fill is better when MoT infections occur later in the season; however, later infections may increase the chance of seed transmission of the pathogen with infected seeds (Igarashi 1990). Small, shriveled seeds can be mixed with normal-appearing seeds on symptomatic spikes (Urashima et al. 2009). MoT is a seedborne pathogen (Fig. 3) and the fungus can be isolated even from asymptomatic seeds. Contaminated seeds are considered to play an important role in MoT long distance dispersion (Goulart and Paiva 1990). Seeds collected from diseased and healthylooking spikes of certain cultivars may have similar degree of infection (Urashima et al. 2009). MoT can be transmitted from spike to seed, and from infected seeds to seedlings (Fig. 3a). Goulart and Paiva (1990) estimated that the rate of MoT transmission from a non-treated seed lot with $21 \%$ incidence could potentially create 400,000 primary inoculum units per hectare. Under laboratory conditions, abundant sporulation can be observed in MoT infected/infested ungerminated seeds (Fig. 3b). As the seedling emerges, the pathogen can colonize new tissues such as coleoptile, stem, and primary leaves (Goulart and Paiva 1990) increasing its capacity for inoculum production.

Strains of the M. oryzae Triticum pathotype can affect all above-ground parts of the plant. However, in contrast to the situation with rice blast and GLS, disease symptoms other than head blast are often not obvious in commercial wheat fields (Igarashi et al. 1986; Igarashi 1990; Cruz et al. 2015a). On leaves, initial macroscopic lesions are water soaked to gray-green. Blast lesions have grey centers during sporulation (Fig. 2c-d), and white to tan centers after sporulation. Mature lesions often have a dark brown to reddish-brown margin that 


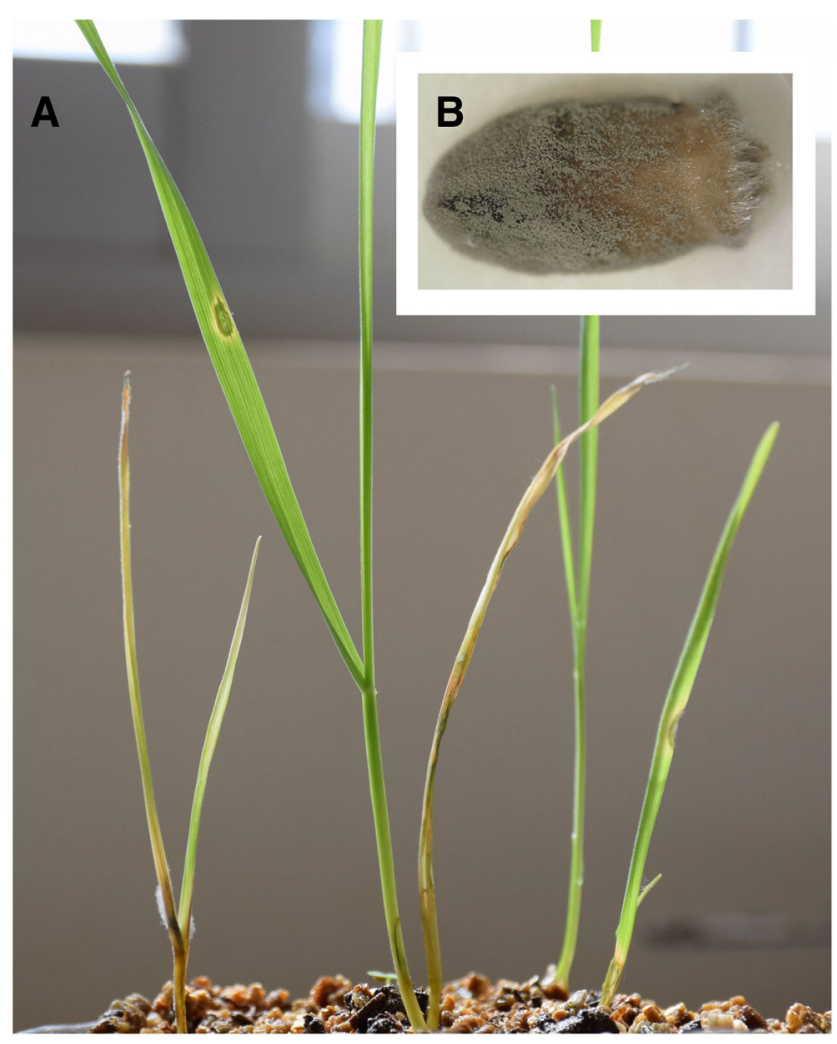

Fig. 3 Magnaporthe oryzae Triticum can be transmitted from infected seeds to seedlings. a These seedlings were grown from infected seeds with no further inoculation. Note typical leaf blast lesions with chlorotic halos. b Extensive sporulation can occur on the surface of naturally infected seeds

stops lesion expansion, and they also often have yellow chlorotic halos (Fig. 3a). Individual lesions are generally eye-spot shaped (sometimes elliptical), but they coalesce in moderate to severely infected seedlings, sometimes resulting in total death of the plant (Rios et al. 2013). Although the largest lesions on rice tend to occur on younger leaves; lesions on wheat occur more frequently on older leaves, including senescent leaves at the base of the plant (Fig. 2d) (Cruz et al. 2015a). Lesions can also rarely be seen on the leaf collar, culm, culm nodes, and stem (Fig. 2e).

\section{Fungal taxonomy and biology}

Collectively, the $M$. grisea species complex causes disease on more than 50 grass species including rice (Oryza sativa L.), wheat (Triticum aestivum L.), finger millet (Eleusine coracana), Italian (foxtail) millet (Setaria italica), perennial and annual ryegrass (Lolium species), oats (Avena sativa), barley (Hordeum vulgare L.) and crabgrass (Digitaria sanguinalis (L.) Scop) (Igarashi et al. 1986; Valent and Chumley 1991; Couch et al. 2005; Marangoni et al. 2013). Pyricularia, the anamorphic name for the fungus, was established by Saccardo (1880) based on the pyriform shape of the asexual conidia of $P$. grisea on crabgrass. In 1892, Cavara designated rice isolates as $P$. oryzae. Sprague (1950) applied Pyricularia species names based on host, with $P$. oryzae for rice isolates and $P$. grisea for isolates from all other cereals and grasses. The sexual morph of $P$. grisea Digitaria isolates was observed in the laboratory in 1970 and eventually designated Magnaporthe grisea based on ascospore morphology (Barr 1977; Yaegashi and Udagawa 1978; Couch and Kohn 2002). Rossman et al. (1990) merged P. oryzae and P. grisea, grouping all host specific forms under the name $P$. grisea. Kato and colleagues (Kato et al. 2000; Tosa et al. 2004) examined pathogenicity, mating compatibility, and RFLPs of Pyricularia isolates from various hosts, and found that isolates from Oryza, Setaria, Panicum, Eleusine, Triticum and Lolium species formed a genetically close, interfertile group (the CC crop isolate group) that was distinct from the crabgrass isolates originally designated $P$. grisea. They suggested the $\mathrm{CC}$ group should become P. oryzae. Couch and Kohn (2002) confirmed the close relationships among the agriculturally-important CC isolates using a multilocus phylogenetic analysis and segregated these pathogens into the separate species M. oryzae. Isolates pathogenic on Digitaria species were retained as M. grisea. This back and forth for genus and species names explains why the rice and wheat blast pathogens are commonly referred to in the blast literature as Pyricularia or Magnaporthe, each with species identifiers of grisea or oryzae.

The decision in 2011 that each fungus should have only one name presented a dilemma for blast researchers due to the common usage of both Pyricularia and Magnaporthe. Therefore, the community decided to retain Magnaporthe as an official synonym of Pyricularia, and both names will continue to be used (Zhang et al. 2016a). Recently, a subset of the wheat pathogen population was moved into a new species, Pyricularia graminis tritici, together with pathogens from finger millet and other grasses, effectively dividing the wheat blast population into two species (Castroagudin et al. 2016). However, the new species is disputed by other researchers and should not be adopted until the picture becomes clear. With next generation sequencing, whole genomes of many blast isolates are becoming available to clarify genetic relationships within the blast family of pathogens (Farman et al. 2017).

The pyriform-shaped asexual conidia of the blast fungus are hyaline to pale gray-colored (Fig. 4a). The fungus can be purified by isolation of a single conidium, because single nuclei in each of the three cells of a conidium are identical. The fungus is a Pyrenomycete, producing predominantly fourcelled ascospores in unordered asci within long-necked perithecia (Fig. 4b). Fully fertile strains are self-sterile hermaphrodites, with compatibility for mating governed by alternate alleles of the mating type locus MAT1. At $\sim 20{ }^{\circ} \mathrm{C}$ with light, highly fertile hermaphroditic strains mate as a female (contributing cytoplasm and producing the perithecium) and as a male in crosses with hermaphroditic strains of opposite mating 
Fig. 4 Three types of spores produced by the wheat blast fungus. (a) Asexual pyriform conidia, reproduced with permission from Zhang et al. (2014). (b) Asexual microconidia produced from phialides, reproduced with permission from Zhang et al. (2014). (c) Depiction of perithecia and ascospores, reproduced with permission from Yaegashi and Udagawa (1978). Scale Bars in $\mathbf{a}$ and $\mathbf{b}: 5$ micrometers
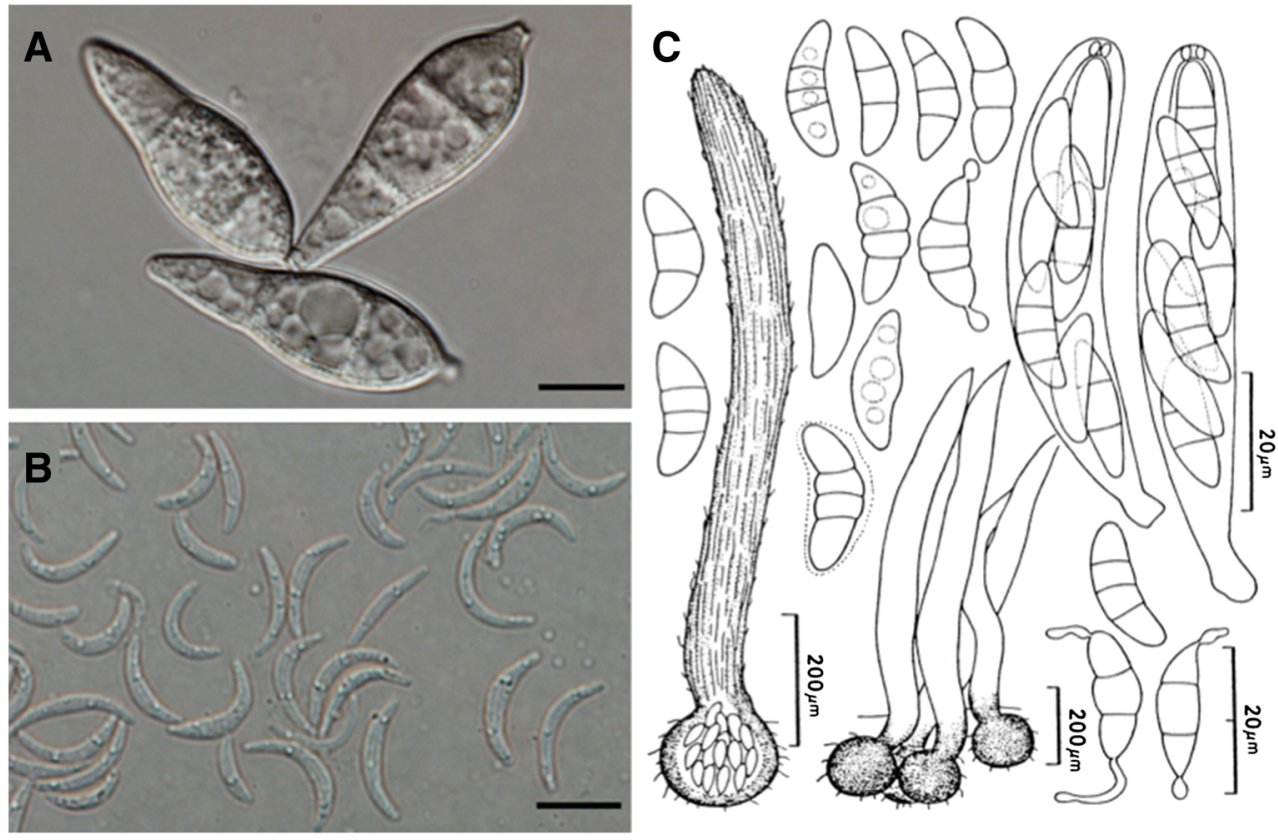

type. Sexually fertile $M$. orzyae strains also produce a Phialophora-like anamorph in which small, crescent-shaped microconidia (Fig. 4c) are produced from phialides (Chuma et al. 2009). These microconidia germinate at low levels and infect plants through wounds, but their role in nature is unknown (Zhang et al. 2014). Both conidia and ascospores germinate and form appressoria on hydrophobic surfaces. Appressoria that develop in water droplets, such as dew, generate very high turgor pressure to puncture the host leaf surface and colonize the tissues. The $\sim 40$ megabase pair $M$. oryzae genome is transposon-rich and contains approximately 13,000 genes on 7 chromosomes (Zhang et al. 2016b). Mechanisms of pathogenicity and cultivar specificity, resulting in a hemibiotrophic lifestyle, have been extensively studied for the rice blast fungus (Giraldo and Valent 2013; Liu et al. 2014; Zhang et al. 2016b). Initial cytological studies of "non-host resistance" have compared infection outcomes on the adapted and non-adapted hosts using M. oryzae isolates from the Oryza, Triticum, and Eleusine pathotypes and M. grisea isolates from Digitaria species. Fungal strains often failed to penetrate non-adapted hosts, and if penetration occurred, they induced post-penetration cytoplasmic-granulation or hypersensitive-like responses characteristic of genefor-gene interactions in rice (Heath et al. 1990; FaivreRampant et al. 2008; Tufan et al. 2012; Araujo et al. 2016).

\section{Host species-specific pathotypes}

Understanding the genetic basis for host specificity of MoT strains is important for disease management because alternative hosts would likely serve as a source of inoculum for wheat and as reservoirs for long-term survival of the pathogen. Extensive genetic research has shown that avirulence (AVR) effectors, which are widely studied as determinants of cultivar specificity in rice blast disease (Valent and Khang 2010; Liu et al. 2014), are also key determinants of M. oryzae host species specificity (Yaegashi 1978; Yaegashi and Asaga 1981; Valent et al. 1991; Tosa et al. 2016). In the classical gene-for-gene interaction (Flor 1971), AVR effector genes encode the pathogen signal molecules that are recognized by corresponding plant resistance $(R)$ gene-encoded receptors to trigger hypersensitive resistance. The first $A V R$-type gene cloned from M. oryzae, named $P W L 2$, was a host species specificity gene that prevents strains that carry it from infecting weeping lovegrass (Eragrostis curvula) (Sweigard et al. 1995). AVR1$C O 39$, which functions as an $A V R$ gene in rice, was apparently gained by an ancestral M. oryzae strain and then lost from the Oryza pathotype by a transposon-mediated deletion event (Tosa et al. 2005, 2006). Five $A V R$ effector-like genes (PWT1-5) from Oryza, Setaria and Avena isolates independently block infection of wheat (Tosa et al. 2006). Tosa and colleagues genetically confirmed a gene-for-gene relationship responsible for incompatibility of a Lolium isolate on wheat (Vy et al. 2014). Specifically, they identified two gene pairs that block infection of wheat: the MoL $A V R$ gene $A l$ and its corresponding wheat $R$ gene $R m g 6$ conferring strong resistance; and the $A V R$ gene $A 2$ and its corresponding $R$ gene $R 2$ conferring weak resistance. An additional wheat $R$ gene $R m g l$ blocks Avena isolates from infecting wheat, and two wheat genes, Rmg4 and Rmg5, independently block Digitaria isolates from infecting wheat (Anh et al. 2015). Therefore, host shifts and emergence of new diseases like wheat blast could easily result from loss of a few $A V R$ genes. The similar mechanism 
controlling rice cultivar specificity and host species specificity supports designation of the host species-specific $M$. oryzae populations as pathotypes. It is important to understand if mechanisms for frequent mutation of AVR genes in rice pathogens also occur in MoT strains (Valent and Khang 2010).

In general, $M$. oryzae isolates collected in nature are considered as specialized for particular host species, but some isolates do appear to cross-infect other host species (Tosa et al. 2004). A confusing picture of host species specificity has emerged in the literature in part because different studies using artificial inoculations sometimes report conflicting results (Urashima et al. 1993; Viji et al. 2001). Inconsistent results between studies may be due to the extreme environmental sensitivity of blast infections. Additionally, some hosts such as annual ryegrass, tall fescue, and weeping lovegrass appear to be 'universal suscepts' with potential for infection by fungal strains from several pathotypes in laboratory studies (Kato et al. 2000; Tosa et al. 2016). Barley is broadly susceptible under laboratory conditions, but there are only a few reports of barley blast in the field, possibly due to cooler climates where barley is grown (Goulart et al. 2003; Lima and Minella 2003). It remains to be determined if these hosts are universally susceptible under field conditions.

A potential source of confusion in defining host species specificity associated with individual $M$. oryzae pathotypes is the demonstrated ability of $M$. oryzae strains to sometimes form lesions on non-adapted hosts. Heath et al. (1990) performed quantitative cytological analyses of outcomes at individual infection sites for a rice isolate and a weeping lovegrass isolate infecting rice, finger millet, and weeping lovegrass. The rice pathogen could form small sporulating lesions on finger millet, but at $\sim 1 \%$ of attempted penetration sites. In contrast, this rice pathogen forms large sporulating lesions at $>80 \%$ of attempted penetration sites in rice. Different plant-by-strain combinations presented a continuum of disease symptoms, ranging from no visible symptoms to non-sporulating dark brown resistance lesions to small susceptible lesions with sporulating centers to the maximum-sized sporulating lesions characteristic of host-adapted strains (Valent et al. 1991). Extensive genetic analysis of a cross between a rice pathogen and a weeping lovegrass pathogen identified both $A V R$ genes controlling rice cultivar specificity and minor genes that control the sizes of the lesions that form on rice (Valent et al. 1991). Therefore, loss of $A V R$ genes would likely lead to a host jump event, permitting more frequent success at individual infection sites, and selection of favorable minor pathogenicity genes would increase aggressiveness on the new host. Due to the complexities, careful cataloging and analysis of strains isolated from documented hosts in the field together with controlled growth room inoculations will be required to understand the true potential for host susceptibility in nature.

Understanding the genetic basis for host species specificity in M. oryzae will predict the potential for 'host-jump' events to create new aggressive populations with potential to spread around the world. Rice blast disease caused by the $\mathrm{MoO}$ population appears to have arisen from a host jump from Setaria pathogens around the time rice was domesticated $\sim 7000$ years ago (Couch et al. 2005). This could have occurred because Italian millet, $S$. italica, was domesticated in the middle Yangtze valley in China around the same time that cultivated rice was domesticated from $O$. rufipogon. The wheat pathogen in Brazil was originally suggested to have jumped from rice because blast was endemic in rice produced in northern Paraná state in 1985 (Igarashi et al. 1986). However, it was soon shown that the rice pathogen population was not the source for wheat blast, based on lack of cross-infectivity of rice and wheat isolates and on the high level of sexual fertility of the wheat isolates compared to local infertile rice isolates (Prabhu et al. 1992; Urashima et al. 1993; Orbach et al. 1996). DNA fingerprinting using band patterns produced by Southern blot hybridization with transposon DNA fragments conclusively refuted a host jump from rice to wheat. For example, wheat pathogens lack the $\sim 50$ copies of the MGR586 transposon found in rice pathogens (Valent and Chumley 1994; Urashima et al. 1999). Indeed, early studies, which did not include Lolium isolates, suggested that wheat isolates were more closely related to finger millet pathogens than to rice pathogens (Urashima et al. 1993).

Diseases on Lolium ryegrass and on wheat were reported before occurrence of the pandemic populations that have moved across and between continents. For example, blast of Lolium ryegrass was reported as a new disease in Louisiana in 1971, yet this disease was not a continuing problem until it occurred as GLS in Pennsylvania in 1991 (Carver et al. 1972; Rush and Carver 1973). Reported factors contributing to the 1971 epidemic were early planting by some farmers, unusually warm weather through November and higher than usual rates of application of nitrogen fertilizers, factors generally known to favor blast disease. Interestingly, it was reported that wheat interplanted with ryegrass at this time in Louisiana was also infected by M. oryzae (Rush and Carver 1973). Independently, M. oryzae was reported to be present on wheat in India (Mcrae 1922) and Pakistan (Malik and Khan 1943). These results suggest that blast disease has occurred periodically on some hosts before becoming a sustained problem. It is important to understand what factors enabled more aggressive forms of MoT and MoL to emerge in 1985 and 1991, respectively.

\section{Population structure and dynamics}

A recent study suggested that MoT follows a mixed reproductive system in which sexual recombination is followed by asexual dispersal of better-adapted clones (Maciel et al. 2014). This is in contrast to rice blast, which has strictly asexual reproduction in most parts of the world (Zeigler 1998). Pathogens with a 
mixed reproductive system are considered to have the highest level of evolutionary potential and to be hardest to control. Indirect evidence suggests that the original MoT population in the 1980s was capable of reproducing sexually. The M. oryzae sexual cycle has never been observed in nature, so its occurrence can only be inferred by frequent isolation of highly fertile hermaphrodites from the field, by isolation of approximately equal frequencies of strains of each mating type, and by evidence of recombination (Zeigler 1998). Additionally, strains that are frequently going through sexual crosses maintain conserved chromosome structure, which is required for proper chromosome segregation and high ascospore viability. Fertile fungal strains fail to accumulate minichromosomes, small dispensable chromosomes that don't segregate properly through meiosis. By all of these indicators, the early Brazilian wheat pathogens were highly fertile. MoT strains isolated in the 1980s and early 1990s were hermaphrodites, producing perithecia and asci with $70-95 \%$ viable ascospores, even when crossed with isolates of other pathotypes (Urashima et al. 1993; Orbach et al. 1996; Tosa et al. 2016). Electrophoretic karyotype gel separations of intact chromosomes showed the expected $7 \mathrm{M}$. oryzae chromosomes and the absence of dispensable mini-chromosomes (Orbach et al. 1996; Tosa et al. 2004). Therefore, sexual reproduction was probably common in the early days of wheat blast disease.

Urashima et al. (2005) defined two distinct populations causing wheat blast epidemics in Brazil in 1998, one sexually fertile and one infertile. A population from a wheat field in Paraná state was infertile, with strains mating only as males or not mating at all. DNA fingerprinting with MGR583 transposon sequences grouped the Paraná isolates into two distinct clonal lineages, characteristic of asexual evolution. In contrast, most isolates from a wheat field in Mato Grosso do Sul state mated as highly fertile hermaphrodites and showed high strain-to-strain variation with no evidence for distinct clonal lineages. Similarly, the GLS pathogen in Japan was comprised of two distinct populations, one sexually fertile and one infertile (Tosa et al. 2004). The 'TALF' population from the east or north of Japan was characterized by low sexual fertility, at best mating only as males, and by uniform MGR583 fingerprints with many ( $>40$ ) bands, but extreme diversity in chromosomes sizes. These strains were highly specific for pathogenicity on Lolium species, and they corresponded to the MoL population in the U.S. In contrast, the 'WK' population from west Japan showed high levels of sexual fertility (most strains were female fertile) and no evidence of clonal lineage structure. These strains had fingerprints with few MGR583 bands and uniform electrophoretic karyotypes. The sexually fertile WK isolates showed intermediate pathogenicity toward Lolium species and wheat. Unlike the TALF isolates that caused significant disease on Lolium species at $20{ }^{\circ} \mathrm{C}$, the WK isolates only caused significant disease at higher temperatures (Tosa et al. 2004). Therefore, it is important to track and understand each distinct population causing wheat blast or GLS, since they have different temperature optima, host specificities and levels of sexual fertility.

The evolutionary history of rice blast might be valuable in predicting evolution of the wheat blast population as it migrates away from its center of origin in Brazil. Although most rice pathogens isolated around the world have low levels of sexual fertility, there is growing evidence that some $\mathrm{MoO}$ populations still reproduce sexually in their putative center of origin in the Himalayan foothills of India and China (Zeigler 1998; Saleh et al. 2012b). Again, this is based on occurrence of frequent female-fertile rice isolates with both mating types, and on evidence of recombination in isolates sampled in consecutive years (Saleh et al. 2012b). In contrast, migration of $\mathrm{MoO}$ strains around the world has been accompanied by loss of female fertility and mating ability. DNA fingerprinting using multi-locus probes clearly divides $\mathrm{MoO}$ field populations in the Americas, Europe and the Philippines into relatively low numbers of distinct clonal lineages, with each lineage apparently derived through asexual propagation from a common ancestor (Zeigler 1998). Some migration events may have involved only one mating type, eliminating potential for sexual recombination. Additionally, sexual fertility in M. oryzae is unstable and easily lost in strains that undergo many cycles of asexual recombination (Saleh et al. 2012a). It is important to document levels of sexual fertility in current MoT populations. It will be important to monitor levels of variation in the MoT population in Bangladesh, which currently appears to be clonally derived from a single strain of one mating type (Malaker et al. 2016). The level of fertility in the Bangladeshi strains will determine if they will be able to cross with native strains on other grasses, creating more potential for variation. Also, if and when wheat blast moves into Northern India, it will be important to determine if the Bangladeshi MoT strains have the opportunity and ability to cross with strains from the fertile rice pathogen population reported to exist in the Himalayan foothills (Zeigler 1998).

\section{Wheat blast ecology and epidemiology}

Blast varies greatly in severity based upon weather conditions, cultivar, and plant organ infected (Goulart et al. 2007; Urashima et al. 2009). A combination of high temperatures, excessive rain, long and frequent leaf wetness, and poor fungicide efficacy has favored the occurrence of this disease during outbreak years (Goulart et al. 2007). For wheat blast, the optimum temperature ranges between 25 and $30{ }^{\circ} \mathrm{C}$ with spike wetness between 25 and $40 \mathrm{~h}$ (Cardoso et al. 2008). These two factors alone can favor wheat blast intensity. Environmental conditions that support disease development appear similar for MoT, MoO and MoL strains (Anderson et al. 1947; 
Uddin et al. 2003a; Cardoso et al. 2008). However, in temperate regions, population sizes for the MoL and $\mathrm{MoO}$ pathotypes appear to be reduced by winter conditions (Kapoor and Singh 1977; Harmon and Latin 2003; Latin and Harmon 2004). Cruz et al. (2016b) reported that the potential distribution of MoT in a temperate country such as the U.S. is likely to be limited by specific temperature and precipitation requirements for fungal infection, and by extreme low temperatures that might limit MoT overwintering survival (Fischer 2016).

Lack of a complete understanding of ecological and epidemiological factors that drive wheat blast epidemics makes disease management a challenging task. It has long been considered that widespread and almost synchronous development of bleached wheat spikes occur in large commercial fields during outbreak years (Cruz et al. 2015a). However, recent studies conducted in North and South America (Cruz et al. 2015a; Rios et al. 2016) provided new insights. Rios et al. (2016) demonstrated that spike blast incidence could increase over time from a known source of inoculum. In addition, wheat producers and blast researchers have reported the presence of hotspots within wheat fields during early epidemic development in Bolivia and Bangladesh. The presence of initial hotspots may imply that reports of synchronous fungal infection were influenced by when obvious symptoms were observed, most likely at later stages of the crop. For instance, entire wheat fields with wheat spike blast symptoms (Fig. 1a) are often reported at the medium milk-to-dough growth stage (Cruz et al. 2016c), but hotspots can occur at earlier stages (K. Mills, J.D. Salgado and P.A. Paul, personal communication). Generally, there is a window of 20 days between full spike emergence (Feekes 10.5) and the medium milk-to-dough stage (Feekes 11.2). Although spike infection is the most visible symptom in the field, over the last few years leaf blast symptoms have increasingly been reported on some wheat cultivars in Bolivia (J. Toledo, personal communication).

Cruz et al. (2015a) reported that MoT isolates caused significantly more disease on the oldest wheat leaves compared to the youngest leaves. This finding is in contrast to the riceblast pathosystem, where young expanding rice leaves are the most susceptible to $M$. oryzae. That is, the largest lesions occur on the youngest rice leaves and sporulation in these lesions occurs at the same time new susceptible rice leaves emerge (Ghatak et al. 2013). Similar to rice blast (Kim 2001), MoT sporulation prior to spike emergence might provide the inoculum (i.e. conidia) that ultimately supports development of epidemics of wheat spike blast (Cruz et al. 2015a; J.M.C. Fernandes, personal communication). A basic question concerns the source of this inoculum in an apparently healthy wheat crop. Cruz et al. (2015a) also reported that M. oryzae saprophytic growth and conidiation on basal senescent leaves (Fig. 2d) coincide with spike emergence under greenhouse and field conditions. MoT sporulation in the field was significantly greater on a susceptible cultivar (Atlax) than on more resistant cultivars. Based on the evidence, Cruz et al. (2015a) proposed that the lower canopy of certain wheat cultivars could play an important role in the initial development of wheat head blast epidemics. However, more research is needed to determine whether the inoculum originating from leaves has a major relevance as a source for spike fungal infection on severely affected commercial fields (Cruz et al. 2015a). In addition, it will be important to determine the relative importance of other potential primary sources of inoculum such as infected seeds (Urashima et al. 1999), crop residue, and conidia from grass species other than wheat (Prabhu et al. 1992; Urashima and Kato 1998). Basic aspects of the wheat blast epidemiology need to be determined including latent and incubation periods, optimum growth stage for infection, microclimate, and the interaction and dynamics of factors that support inoculum build-up and widespread epidemics (Cruz et al. 2015a; Rios et al. 2016).

\section{Detection methods}

Disease management strategies require accurate detection of low levels of a pathogen before disease symptoms are easily observed. Magnaporthe oryzae-specific transposable element sequences such as Pot2, MGR583 and MoTeR have been useful for identification of $M$. oryzae, but they do not differentiate MoT isolates from isolates of other host-specific pathotypes (Farman 2002; Pieck et al. 2016). Recently, a quantitative loop-mediated isothermal amplification (qLAMP) assay was coupled with a spore trap system for quantification of airborne inoculum of the Lolium pathotype in turf field plots in the U.S. (Villari et al. 2017). This proof of concept study demonstrated detection of as few as 10 conidia up to 12 days before symptoms developed in inoculated turf grass plots. It is currently unknown if this assay would also detect the closely related MoT isolates. Pieck et al. (2016) used whole genome analysis to identify DNA sequences that differentiate MoT isolates from other host specific forms including MoL isolates. A polymerase chain reaction (PCR)based diagnostic assay using the sequence MoT3 shows specificity and sensitivity in laboratory studies and is now being developed as a tool for detecting the wheat blast pathogen in the field and in wheat seed or grain lots from affected areas. Deploying effective diagnostic assays is urgently needed.

\section{Disease management}

Genetic resistance Resistance to wheat blast remains elusive despite intense searches for sources of resistance since 1985 (Urashima et al. 2004; Prestes et al. 2007; Cruz et al. 2010, 2016c). Similar to the rice blast pathosystem, genetic studies 
show that wheat blast follows a gene-for-gene relationship (Flor 1971; Silué et al. 1992; Anh et al. 2015). Studies also show significant isolate-by-cultivar interactions and multiple virulence differences (physiological races) within MoT populations (Urashima et al. 2004; Maciel et al. 2014; Cruz et al. 2016c). However, while dozens of blast $R$ genes have been identified in rice (Liu et al. 2014), blast $R$ genes appear to be rare in wheat (Cruz et al. 2016c).

Although wheat blast can be both a spike and a leaf disease, poor correlation is observed between the two reactions (Cruz et al. 2012; Maciel et al. 2014), possibly indicating different resistance mechanisms. Both qualitative and quantitative blast resistance are present in wheat; but the former is mainly validated at the seedling stage, and further studies are needed for verification at the adult plant and spike stages (Maciel et al. 2014). In addition to the previously discussed wheat $R$ genes that prevent infection by $M$. oryzae isolates of the Oryza, Setaria and Avena pathotypes, four wheat $R$ genes have been identified against $M o T$ strains (Anh et al. 2015). Rmg2 and Rmg3 from bread wheat variety Thatcher confer seedling resistance to MoT strains isolated from 1990 to 1992, but highly-aggressive strains isolated since 2011 devastate Thatcher and therefore appear to have overcome these genes. Rmg7 from tetraploid T. dicoccum and Rmg8 from bread wheat conferred resistance when fungal infection with strains from 1990 to 1992 occurred on both seedlings and spikes (Anh et al. 2015). However, Rmg7 does not confer resistance to the recent MoT isolates, and $R m g 8$ remains to be tested with current MoT isolates and with natural field populations. These results and others suggest that the current MoT population has become more aggressive toward wheat and that it has already overcome some resistance sources.

Cruz et al. (2016c) identified a wheat head blast resistance trait contained on a wild wheat chromosome segment (the 2NS translocation segment from Aegilops ventricosa). Field tests in Bolivia in 2014 and 2015 confirmed that the 2NS segment confers head blast resistance under natural epidemic conditions. The 2NS-chromosome fragment has already been incorporated into diverse cultivated wheat varieties due to its useful rust and nematode $R$ genes. Popular wheat varieties derived from the CIMMYT line, Milan, were released in the past due to their relatively high levels of head blast resistance in the field (Kohli et al. 2011), and Milan contains the 2NS segment (Cruz et al. 2016c). Urubó-CIAT (Milan/Munia) has shown high levels of blast resistance under field (Cruz et al. 2016c) and laboratory conditions. Therefore, it is recommended that breeders around the world use 2NS-based cultivars as resistant parents. However, it is important to note that not all lines with 2NS show a significant reduction in head blast (Cruz et al. 2016c) and resistant parents should be selected with caution.

Identification and deployment of novel sources of resistance is imperative and the search for effective resistance is underway in Bangladesh, Bolivia, Brazil, and Paraguay. A recently published standardized inoculation protocol for testing wheat for reaction to spike blast will facilitate worldwide communication of data on the reaction of wheat germplasm (Cruz et al. 2016a). Hybridization between 2NS and non-2NS lines with promising head blast resistance is necessary. Modern technologies, including advanced plant breeding and phenotyping platforms, should be used to discover novel sources of resistance and speed up development of resistant germplasm. The long-term success of breeding for blast resistance will be influenced by i) availability, diversity, and type of genetic resistance, ii) screening methodology and selection environment for tracking resistance, and iii) nature of the pathogen and diversity of virulence in the population.

Cultural and chemical control In Bolivia, Brazil, and Paraguay, delaying the planting date has significantly reduced yield losses (Coelho et al. 2016). This practice is used to avoid wheat heading during periods of high temperatures, high precipitation, and high relative humidity (Mehta et al. 1992). Silicon treatment enhances resistance to wheat blast (Cruz et al. 2015b). Deep plowing of infected plant residues and elimination of possible alternate hosts have also been recommended (Urashima 2010).

Although there is evidence in South America that fungicides can provide some level of head blast control, other results suggest that their efficacy may be limited and insufficient. The consensus opinion is that fungicides are not effective in controlling wheat head blast if warm, rainy weather occurs during the heading stage (Goulart et al. 2007; Urashima et al. 2009). Some studies show that fungicides partially control wheat head blast and offer better control on cultivars with at least moderate levels of resistance (Kohli et al. 2011; Rios et al. 2016). Rocha et al. (2014), found that the control provided by fungicide applications was only effective on flag leaves, but not on heads. It is unknown if poor control is due to improper timing or incomplete application, poor active ingredient activity, low doses, poor coverage or extreme weather conditions during application. Cruz et al. (2015a) proposed that earlier fungicide applications might reduce MoT inoculum from basal leaves and thus lower the risk of fungal infections on spikes. Because the wheat blast pathogen is seedborne, another management strategy is seed treatment with fungicides. Bockus et al. (2015) reported that effective fungicides reduced MoT sporulation by 52.2 to $100 \%$ relative to a non-treated control. According to Toledo (2015), an effective seed treatment can eradicate MoT primary inoculum. For this reason, fungicide treatment of seed lots originating from fields affected by blast should be mandatory (Toledo 2015).

Widespread fungicide resistance would limit fungicide efficacy. Extensive use of strobilurin (QoI) fungicides in Brazil has led to widespread distribution of $c y t b$ mutations 
conferring resistance in strains isolated from wheat and other grasses (Castroagudín et al. 2014). Therefore, fungicide resistance in the MoT population should be routinely monitored.

Germplasm exchange Exchange of wheat germplasm is critical for identification and testing of new resistance resources. However, MoT infected/infested seeds can serve as a vehicle for the introduction of the fungus into non-endemic areas (Goulart and Paiva 1990, 1991, 1993). Therefore, extensive measures need to be taken to prevent the entry and establishment of MoT into new countries (Cruz et al. 2016b). Biologically-sound risk mitigation plans should be implemented for importation of wheat seeds from countries where wheat blast is endemic. General guidelines to promote safe germplasm movement, including standard seed production and preparation procedures should be implemented (Mezzalama 2016). Field inspections, harvest procedures, and storehouse maintenance, in addition to seed testing, treatment, and packing, should be implemented prior to movement of germplasm (Mezzalama 2016).

\section{Future challenges}

Wheat blast control presents additional challenges compared to rice blast, although rice blast remains the most explosive and potentially damaging disease on rice worldwide. The highly variable rice blast fungus remains a problem due to its ability to quickly overcome $R$ genes that are deployed in rice in the field. Additional challenges for wheat blast include the scarcity of identified $R$ genes in wheat and the lack of control of head blast by fungicides when the weather favors disease. Promising wheat $R$ genes identified with MoT strains isolated in the 1980s and 1990s are no longer effective against the more aggressive strains recently isolated from the field in South America. This underscores the urgent need for global collaboration and resources to combat this new threat to wheat production. The 2NS-based cultivars are currently the best sources of resistance to wheat head blast, but this resistance must be backed up with additional resistance. So far, only a few promising lines with non-2NS resistance have been identified under controlled environment conditions and testing of these lines under natural epidemic conditions is pending. Precision phenotyping platforms are required to increase the efficiency of discovery of novel sources of resistance. On a parallel front, effort should include testing if any of the cloned rice $R$ genes will function to protect wheat against blast. Transgenic and genome-editing strategies based on the detailed understanding of the fungal infection process and wheat resistance mechanisms could provide longer-term solutions, which means that foundational research on wheat blast disease should also become a priority.
Control of wheat blast will require the development of effective and integrated management strategies aimed at reducing the losses associated with this disease. This requires research on the ecology of $M$. oryzae pathotypes that threaten wheat and disease epidemiology of wheat blast. It is critical to clarify which alternative hosts can harbor the MoT pathotype. More research is needed to identify the main source(s) of inoculum in the field and to understand the dynamics of inoculum build-up and the significance of both auto- and alloinfections in the wheat-blast pathosystem. It is critical to define incubation and latent periods, optimum plant growth stages for infection, and critical microclimate details.

Large-scale movement of wheat through the global grain trade distribution system could provide opportunity to move the pathogen inadvertently (Cruz et al. 2016b). However, proving the importance of MoT seedborne inoculum would require large-scale field experiments. Remote sensing, "ground truth", and molecular diagnostics methods will be necessary to determine if MoT seedborne inoculum is epidemiologically important. Early detection of signs and symptoms in commercial fields is key to controlling wheat blast. Recent diagnostic assays developed to detect MoT isolates must be coupled with appropriate sampling methods to assist in tracking the MoT fungus in seed and in the field (Pieck et al. 2016). It is critical to determine if limited control by fungicides is associated with improper timing, incomplete application, poor coverage or ineffective active ingredients. An integrated approach will aid in reducing the likelihood of boomand-bust cycles and increase the lifetime of resistance genes. Better surveillance systems, preparedness infrastructure, prevention and control tools must be developed, especially in countries at risk.

Acknowledgements The authors would like to thank Bolivian collaborators Ing. Guillermo Barea, Ing. Edgar Guzman, Ing. Marcia Gabriela Rivadeneira, Ing. Javier Toledo, Ing. Maria Isabel Cazón, Ing. Diego Baldelomar and partners at Asociación de Productores de Oleaginosas y Trigo (ANAPO), CAICO-Fundación CETABOL, Centro de Investigación Agrícola Tropical (CIAT), and Universidad Autónoma Gabriel René Moreno for their continuous collaborations. Ing. Guillermo Barea and Javier Toledo provided some of the photos published in this manuscript. Our research on wheat blast disease has been funded by Agriculture and Food Research Initiative Competitive Grants 2009-55605-05201 and 2013-68004-20378 (Blast Integrated Project) from the United States Department of Agriculture National Institute of Food and Agriculture (USDA-NIFA). This is contribution number 17294-J from the Kansas Agricultural Experiment Station.

Open Access This article is distributed under the terms of the Creative Commons Attribution 4.0 International License (http:// creativecommons.org/licenses/by/4.0/), which permits unrestricted use, distribution, and reproduction in any medium, provided you give appropriate credit to the original author(s) and the source, provide a link to the Creative Commons license, and indicate if changes were made. 


\section{References}

Anderson A, Henry B, Tullis E (1947) Factors affecting infectivity, spread and persistence of Pyricularia oryzae Cav. Phytopathology 37:94-110

Anh VL, Anh NT, Tagle AG, Vy TTP, Inoue Y, Takumi S, Chuma I, Tosa Y (2015) Rmg8, a new gene for resistance to Triticum isolates of Pyricularia oryzae in hexaploid wheat. Phytopathology 105:15681572

Araujo L, Soares JM, De Filippi MCC, Rodrigues FA (2016) Cytological aspects of incompatible and compatible interactions between rice, wheat and the blast pathogen Pyricularia oryzae. Sci Agric 73:177183

Barea G, Toledo J (1996) Identificación y zonificación de piricularia o bruzone (Pyricularia oryzae) en el cultivo del trigo en el dpto. de Santa Cruz. CIAT. Informe Técnico. Proyecto de Investigación Trigo, Santa Cruz, pp 76-86

Barr ME (1977) Magnaporthe, Telimenella, and Hyponectria (Physosporellaceae). Mycologia 69:952-966

Bockus WW, Cruz CD, Stack JP, Valent B (2015) Effect of seedtreatment fungicides on sporulation of Magnaporthe oryzae from wheat seed. Plant Disease Manag Rep 9:ST004

Cabrera MG, Gutiérrez S (2007) Primer registro de Pyricularia grisea en cultivos de trigo del NE de Argentina. Jornada de Actualización en Enfermedades de Trigo. IFSC Press, Lavallol, Buenos Aires

Cardoso CDA, Reis EM, Moreira EN (2008) Development of a warning system for wheat blast caused by Pyricularia grisea. Summa Phytopathol 34:216-221

Carver R, Rush M, Lindberg D (1972) An epiphytotic of ryegrass blast in Louisiana. Plant Dis Rep 56:157-159

Castroagudín VL, Ceresini PC, De Oliveira SC, Reges JTA, Maciel JLN, Bonato ALV, Dorigan AF, Mcdonald BA (2014) Resistance to QoI fungicides is widespread in Brazilian populations of the wheat blast pathogen Magnaporthe oryzae. Phytopathology 105:284-294

Castroagudin VL, Moreira SI, Pereira DS, Moreira SS, Brunner PC, Maciel JLN, Crous PW, Mcdonald BA, Alves E, Ceresini PC (2016) Pyricularia graminis-tritici, a new Pyricularia species causing wheat blast. Persoonia 37:199-216

Chuma I, Shinogi T, Hosogi N, Ikeda K-I, Nakayashiki H, Park P, Tosa Y (2009) Cytological characteristics of microconidia of Magnaporthe oryzae. J Gen Plant Pathol 75:353-358

Coelho MDO, Torres GM, Cecon PR, Santana FM (2016) Sowing date reduces the incidence of wheat blast disease. Pesq Agropec Bras 51: 631-637

Couch BC, Kohn LM (2002) A multilocus gene genealogy concordant with host preference indicates segregation of a new species, Magnaporthe oryzae, from M. grisea. Mycologia 94:683-693

Couch BC, Fudal I, Lebrun M-H, Tharreau D, Valent B, Van Kim P, Notteghem J-L, Kohn LM (2005) Origins of host-specific populations of the blast pathogen Magnaporthe oryzae in crop domestication with subsequent expansion of pandemic clones on rice and weeds of rice. Genetics 170:613-630

Cruz MFA, Prestes AM, Maciel JLN, Scheeren PL (2010) Partial resistance to blast on common and synthetic wheat genotypes in seedling and in adult plant growth stages. Trop Plant Pathol 35:24-31

Cruz CD, Bockus WW, Stack JP, Tang X, Valent B, Pedley KF, Peterson GL (2012) Preliminary assessment of resistance among U.S. wheat cultivars to the Triticum pathotype of Magnaporthe oryzae. Plant Dis 96:1501-1505

Cruz CD, Kiyuna J, Bockus WW, Todd TC, Stack JP, Valent B (2015a) Magnaporthe oryzae conidia on basal wheat leaves as a potential source of wheat blast inoculum. Plant Pathol 64:1491-1498

Cruz MFA, Debona D, Rios JA, Barros EG, Rodrigues FA (2015b) Potentiation of defense-related gene expression by silicon increases wheat resistance to leaf blast. Trop Plant Pathol 40:394-400
Cruz CD, Bockus WW, Stack JP, Valent B, Maciel JN, Peterson GL (2016a) A standardized inoculation protocol to test wheat cultivars for reaction to head blast caused by Magnaporthe oryzae (Triticum pathotype). Plant Health Prog: PHP-BR-16-0041

Cruz CD, Magarey RD, Christie DN, Fowler GA, Fernandes JM, Bockus WW, Valent B, Stack JP (2016b) Climate suitability for Magnaporthe oryzae Triticum pathotype in the United States. Plant Dis 100:1979-1987

Cruz CD, Peterson GL, Bockus WW, Kankanala P, Dubcovsky J, Jordan KW, Akhunov E, Chumley F, Baldelomar FD, Valent B (2016c) The 2NS translocation from Aegilops ventricosa confers resistance to the Triticum Pathotype of Magnaporthe oryzae. Crop Sci 56:990-1000

Dos Anjos JRN, Dasilva DB, Charchar MJD, Rodrigues GC (1996) Occurrence of blast fungus (Pyricularia grisea) on wheat and rye in the savanna region of central Brazil. Pesq Agropec Bras $31: 79-82$

Faivre-Rampant $\mathrm{O}$, Thomas $\mathrm{J}$, Allègre $\mathrm{M}$, Morel $\mathrm{J}-\mathrm{B}$, Tharreau $\mathrm{D}$, Nottéghem J-L, Lebrun M-H, Schaffrath U, Piffanelli P (2008) Characterization of the model system rice-Magnaporthe for the study of nonhost resistance in cereals. New Phytol 180:899-910

Farman ML (2002) Pyricularia grisea isolates causing gray leaf spot on perennial ryegrass (Lolium perenne) in the United States: relationship to $P$. grisea isolates from other host plants. Phytopathology 92: 245-254

Farman M, Peterson GL, Chen L, Starnes JH, Valent B, Bachi P, Murdock L, Hershman DE, Pedley KF, Fernandes JMC, Bavaresco J (2017) The Lolium pathotype of Magnaporthe oryzae recovered from a single blasted wheat plant in the United States. Plant Dis 101:684692

Fischer T (2016) Influence of freezing on the survival of Magnaporthe oryzae and weather conditions that favor blast epidemics in rice. MS Thesis. Kansas State University. Manhattan.

Flor HH (1971) Current status of the gene-for-gene concept. Annu Rev Phytopathol 9:275-296

Ghatak A, Willocquet L, Savary S, Kumar J (2013) Variability in aggressiveness of rice blast (Magnaporthe oryzae) isolates originating from rice leaves and necks: a case of pathogen specialization? PLoS One 8:e66180

Giraldo MC, Valent B (2013) Filamentous plant pathogen effectors in action. Nat Rev Microbiol 11:800-814

Goulart ACP, Paiva FA (1990) Transmission of Pyricularia oryzae by wheat Triticum aestivum seeds. Fitopatol Bras 15:359-362

Goulart ACP, Paiva FA (1991) Control of Pyricularia oryzae and Helminthosporium sativum through wheat seeds treatment with fungicides. Pesq Agropec Bras 26:1983-1988

Goulart ACP, Paiva FA (1992) Incidência da brusone (Pyricularia oryzae) em diferentes cultivares de trigo (Triticum aestivum) em condições de campo. Fitopatol Bras 17:321-325

Goulart ACP, Paiva FA (1993) Evaluation of fungicides in the control of wheat (Triticum aestivum) blast (Pyricularia oryzae). Fitopatol Bras 18:167-173

Goulart ACP, Paiva FA (2000) Perdas no rendimento de grãos de trigo causada por Pyricularia grisea, nos anos de 1991 e 1992, no Mato Grosso do Sul. Summa Phytopathol 26:279-282

Goulart ACP, Paiva FA, Mesquita AN (1990) Occurrence of wheat blast Pyricularia oryzae in the state of Mato Grosso do Sul Brazil. Fitopatol Bras 15:112-114

Goulart ACP, Amabili RF, Nasser LCB, Freitas MA (2003) Detection of Pyricularia grisea on barley seeds produced under central pivot irrigation in the Brazilian Cerrado. Fitopatol Bras 28:566

Goulart ACP, Sousa PG, Urashima AS (2007) Damages in wheat caused by infection of Pyricularia grisea. Summa Phytopathol 33:358-363

Harmon PF, Latin R (2003) Gray leaf spot of perennial ryegrass. Plant Health Prog. doi:10.1094/PHP-2003-1223-01-DG 
Heath MC, Valent B, Howard RJ, Chumley FG (1990) Interactions of two strains of Magnaporthe grisea with rice, goosegrass, and weeping lovegrass. Can J Bot 68:1627-1637

Igarashi S (1990) Update on wheat blast (Pyricularia oryzae) in Brazil. In: Saunders DA (ed) Wheat for the nontraditional warm areas: a proceedings of the international conference. Foz do Iguaçu, Brazil, pp 480-483

Igarashi S, Utiamada CM, Igarashi LC, Kazuma AH, Lopes RS (1986) Pyricularia em trigo. 1. Ocorrência de Pyricularia sp. no estado do Paraná. Fitopatol Bras 11:351-352

Islam MT, Croll D, Gladieux P, Soanes DM, Persoons A, Bhattacharjee P, Hossain MS, Gupta DR, Rahman MM, Mahboob MG, Cook N, Salam MU, Surovy MZ, Sancho VB, Maciel JLN, Nhani A, Castroagudin VL, Reges JTD, Ceresini PC, Ravel S, Kellner R, Fournier E, Tharreau D, Lebrun MH, Mcdonald BA, Stitt T, Swan D, Talbot NJ, Saunders DGO, Win J, Kamoun S (2016) Emergence of wheat blast in Bangladesh was caused by a South American lineage of Magnaporthe oryzae. BMC Biol 14:11

Kapoor AS, Singh BM (1977) Overwintering of Pyricularia oryzae in Himachal Pradesh India. Indian Phytopathol 30:213-216

Kato H, Yamamoto M, Yamaguchi-Ozaki T, Kadouchi H, Iwamoto Y, Nakayashiki H, Tosa Y, Mayama S, Mori N (2000) Pathogenicity, mating ability and DNA restriction fragment length polymorphisms of Pyricularia populations isolated from Gramineae, Bambusideae and Zingiberaceae plants. J Gen Plant Pathol 66:30-47

Kim K (2001) A simulation model to determine infection periods of Magnaporthe grisea and to predict progress of rice leaf blast severity based on near real-time weather data. PhD Thesis. Seoul National University. Seoul, South Korea

Kohli MM, Mehta YR, Guzman E, Viedma L, Cubilla LE (2011) Pyricularia blast - a threat to wheat cultivation. Czech J Genet Plant Breed 47:S130-S134

Latin R, Harmon P (2004) Managing gray leaf spot in the Midwest. Golf Course Management 72:89-92

Lima MIPM, Minella E (2003) Occurrence of head blast in barley. Fitopatol Bras 28:207-207

Liu WD, Liu JL, Triplett L, Leach JE, Wang GL (2014) Novel insights into rice innate immunity against bacterial and fungal pathogens. Annu Rev Phytopathol 52:213-241

Maciel JLN (2011) Magnaporthe oryzae, the blast pathogen: current status and options for its control. CAB Reviews: Perspectives in Agriculture, Veterinary Science, Nutrition and Natural Resources $6: 1-8$

Maciel JLN, Ceresini PC, Castroagudin VL, Zala M, Kema GHJ, Mcdonald BA (2014) Population structure and pathotype diversity of the wheat blast pathogen Magnaporthe oryzae 25 years after its emergence in Brazil. Phytopathology 104:95-107

Malaker PK, Barma NCD, Tiwari TP, Collis WJ, Duveiller E, Singh PK, Joshi AK, Singh RP, Braun HJ, Peterson GL, Pedley KF, Farman ML, Valent B (2016) First report of wheat blast caused by Magnaporthe oryzae pathotype triticum in Bangladesh. Plant Dis 100:2330-2330

Malik SA, Khan MA (1943) Parasitic fungi of the north-west Frontier Province. Indian J Agr Sci 13:522-527

Marangoni MS, Nunes MP, Fonseca N Jr, Mehta YR (2013) Pyricularia blast on white oats: a new threat to wheat cultivation. Trop Plant Pathol 38:198-202

Mcmullen M, Jones R, Gallenberg D (1997) Scab of wheat and barley: a re-emerging disease of devastating impact. Plant Dis 81:1340-1348

Mcrae W (1922) Report of the imperial mycologist - Pusa scientific research institute scientific reports 1921-22. Review of Applied Mycology 2:258-260

Mehta YR, Riede CR, Campos LC, Kohli MM (1992) Integrated management of major wheat diseases in Brazil: an example for the southern cone region of Latin America. Crop Prot 11:517-524
Mezzalama M (2016) Seed health: fostering the safe distribution of maize and wheat seed - general guidelines, Fourth edn. CIMMYT, Mexico

Orbach MJ, Chumley FG, Valent B (1996) Electrophoretic karyotypes of Magnaporthe grisea pathogens of diverse grasses. Mol PlantMicrobe Interact 9:261-271

Perello A, Martinez L, Molina M (2015) First report of virulence and effects of Magnaporthe oryzae isolates causing wheat blast in Argentina. Plant Dis 99:1177-1178

Picinini EC, Fernandes JMC (1990) Occurrence of wheat blast Pyricularia oryzae in commercial fields in the state of Rio Grande do Sul Brazil. Fitopatol Bras 15:83-84

Pieck ML, Ruck A, Farman ML, Peterson GL, Stack JP, Valent B, Pedley KF (2016) Genomics-based marker discovery and diagnostic assay development for wheat blast. Plant Dis 101:103-109

Prabhu AS, Filippi MC, Castro N (1992) Pathogenic variation among isolates of Pyricularia oryzae infecting rice, wheat, and grasses in Brazil. Trop Pest Manag 38:367-371

Prestes AM, Arendt PF, Fernandes JMC, Scheeren PL (2007) Resistance to Magnaporthe grisea among Brazilian wheat genotypes. SpringerVerlag GmbH, Heidelberg

Rios JA, Debona D, Duarte HSS, Rodrigues FA (2013) Development and validation of a standard area diagram set to assess blast severity on wheat leaves. Eur J Plant Pathol 136:603-611

Rios JA, Rios VS, Paul PA, Souza MA, Araujo L, Rodrigues FA (2016) Fungicide and cultivar effects on the development and temporal progress of wheat blast under field conditions. Crop Prot 89:152160

Rocha J, Pimentel A, Ribeiro G, De Souza M (2014) Eficiência de fungicidas no controle da brusone em trigo. Summa Phytopathol 40:347-352

Rossman AY, Howard RJ, Valent B (1990) Pyricularia grisea, the correct name for the rice blast fungus. Mycologia 82:509-512

Rush MC, Carver RB (1973) Ryegrass blast: a serious new disease in Louisiana. Louisiana Agriculture 16:15

Saccardo P (1880) Fungorum extra-europaeorum Pugillus. Michelia 2: 136-149

Saleh D, Milazzo J, Adreit H, Tharreau D, Fournier E (2012a) Asexual reproduction induces a rapid and permanent loss of sexual reproduction capacity in the rice fungal pathogen Magnaporthe oryzae: results of in vitro experimental evolution assays. BMC Evol Biol 12: 42. doi:10.1186/1471-2148-12-42

Saleh D, Xu P, Shen Y, Li C, Adreit H, Milazzo J, Ravigné V, Bazin E, Nottéghem J-L, Fournier E, Tharreau D (2012b) Sex at the origin: an Asian population of the rice blast fungus Magnaporthe oryzae reproduces sexually. Mol Ecol 21:1330-1344

Silué D, Notteghem JL, Tharreau D (1992) Evidence for a gene-for-gene relationship in the Oryza sativa-Magnaporthe grisea pathosystem. Phytopathology 82:577-580

Sprague R (1950) Diseases of cereals and grasses in North America. Ronald Press Com, New York

Sweigard JA, Carroll AM, Kang S, Farrall L, Chumley FG, Valent B (1995) Identification, cloning, and characterization of $P W L 2$, a gene for host species specificity in the rice blast fungus. Plant Cell 7: $1221-1233$

Toledo J (2015) Tratamiento de Semillas. In. Manual de recomendaciones técnicas - Cultivo de trigo. Santa Cruz, Bolivia. Asociación de Productores de Oleaginosas y Trigo (ANAPO), $140 \mathrm{p}$.

Tosa Y, Hirata K, Tamba H, Nakagawa S, Chuma I, Isobe C, Osue J, Urashima AS, Don LD, Kusaba M, Nakayashiki H, Tanaka A, Tani T, Mori N, Mayama S (2004) Genetic constitution and pathogenicity of Lolium isolates of Magnaporthe oryzae in comparison with host species-specific pathotypes of the blast fungus. Phytopathology 94 : 454-462

Tosa Y, Osue J, Eto Y, Oh HS, Nakayashiki H, Mayama S, Leong SA (2005) Evolution of an avirulence gene, AVR1-CO39, concomitant 
with the evolution and differentiation of Magnaporthe oryzae. Mol Plant-Microbe Interact 18:1148-1160

Tosa Y, Tamba H, Tanaka K, Mayama S (2006) Genetic analysis of host species specificity of Magnaporthe oryzae isolates from rice and wheat. Phytopathology 96:480-484

Tosa Y, Uddin W, Viji G, Kang S, Mayama S (2007) Comparative genetic analysis of Magnaporthe oryzae isolates causing gray leaf spot of perennial ryegrass turf in the United States and Japan. Plant Dis 91: $517-524$

Tosa Y, Inoue Y, Trinh TPV, Chuma I (2016) Genetic and molecular analyses of the incompatibility between Lolium isolates of Pyricularia oryzae and wheat. Physiol Mol Plant Pathol 95:84-86

Tufan HA, Mcgrann GRD, Maccormack R, Boyd LA (2012) TaWIR1 contributes to post-penetration resistance to Magnaporthe oryzae, but not Blumeria graminis f. Sp tritici, in wheat. Mol Plant Pathol 13:653-665

Uddin W, Serlemitsos K, Viji G (2003a) A temperature and leaf wetness duration-based model for prediction of gray leaf spot of perennial ryegrass turf. Phytopathology 93:336-343

Uddin W, Viji G, Vincelli P (2003b) Gray leaf spot (blast) of perennial ryegrass turf: an emerging problem for the turfgrass industry. Plant Dis $87: 880-889$

Urashima AS (2010) Wheat blast. In: Bockus WW, Bowden RL, Hunger RM, Murray TD, Smiley RW (eds) Compendium of wheat diseases and pests. American Phytopathological Society Press, St. Paul, pp $22-23$

Urashima AS, Kato H (1998) Pathogenic relationship between isolates of Pyricularia grisea of wheat and other hosts at different host development stages. Fitopatol Bras 23:30-35

Urashima AS, Galbieri R, Stabili A (2005) DNA fingerprinting and sexual characterization revealed two distinct populations of Magnaporthe grisea in wheat blast from Brazil. Czech J Genet Plant Breed 41:238-245

Urashima AS, Igarashi S, Kato H (1993) Host range, mating type and fertility of Pyricularia grisea from wheat in Brazil. Plant Dis 77: 1211-1216

Urashima AS, Hashimoto Y, Don Y, Kusaba M, Tosa Y, Nakayashiki H, Mayama S (1999) Molecular analysis of the wheat blast population in Brazil with a homolog of retrotransposon MGR583. Ann Phytopathol Soc Jpn 65:429-436

Urashima AS, Lavorent NA, Goulart ACP, Mehta YR (2004) Resistance spectra of wheat cultivars and virulence diversity of Magnaporthe grisea isolates in Brazil. Fitopatol Bras 29:511-518

Urashima AS, Grosso C, Stabili A, Freitas E, Silva D, Netto D, Franco I, Bottan M (2009) Effect of Magnaporthe grisea on seed germination, yield and quality of wheat. In: Wang GL, Valent B (eds) Advances in genetic, Genomics and Control of Rice Blast Disease. Springer, Netherlands, pp 267-277

Valent B, Chumley FG (1991) Molecular genetic analysis of the rice blast fungus, Magnaporthe grisea. Annu Rev Phytopathol 29:443-467

Valent B, Chumley FG (1994) Avirulence genes and mechanisms for genetic instability in the rice blast fungus. In: Zeigler RS, Leong SA, Teng PS (eds) Rice blast disease. CAB International, Wallingford, pp 111-134

Valent B, Khang CH (2010) Recent advances in rice blast effector research. Curr Opin Plant Biol 13:434-441

Valent B, Farrall L, Chumley FG (1991) Magnaporthe grisea genes for pathogenicity and virulence identified through a series of backcrosses. Genetics 127:87-101

Viedma LQ (2005) Wheat blast occurrence in Paraguay. Phytopathology 95:S152

Viji G, Wu B, Kang S, Uddin W, Huff DR (2001) Pyricularia grisea causing gray leaf spot of perennial ryegrass turf: population structure and host specificity. Plant Dis 85:817-826

Villari C, Mahaffee WF, Mitchell TK, Pedley KF, Pieck ML, Hand FP (2017) Early detection of airborne inoculum of Magnaporthe oryzae in turfgrass fields using a quantitative LAMP assay. Plant Dis 101: $170-177$

Vy T, Hyon G-S, Nga N, Thithanh IY, Chuma I, Tosa Y (2014) Genetic analysis of host-pathogen incompatibility between Lolium isolates of Pyricularia oryzae and wheat. J Gen Plant Pathol 80:59-65

Yaegashi H (1978) Inheritance of pathogenicity in crosses of Pyricularia isolates from weeping love grass and finger millet. Ann Phytopathol Soc Jpn 44:626-632

Yaegashi H, Asaga K (1981) Further studies on the inheritance of pathogenicity in crosses of Pyricularia oryza with Pyricularia sp. from finger millet. Ann Phytopathol Soc Jpn 47:677-679

Yaegashi H, Udagawa S (1978) Taxonomical identity of perfect state of Pyricularia grisea and its allies. Can J Bot-Rev Can Bot 56:180 183

Zeigler RS (1998) Recombination in Magnaporthe grisea. Annu Rev Phytopathol 36:249-275

Zhang HL, Wu ZS, Wang CF, Li Y, Xu JR (2014) Germination and infectivity of microconidia in the rice blast fungus Magnaporthe oryzae. Nat Commun 5:4518. doi:10.1038/ncomms5518

Zhang N, Luo J, Rossman AY, Aoki T, Chuma I, Crous PW, Dean R, De Vries RP, Donofrio N, Hyde KD, Lebrun M-H, Talbot NJ, Tharreau D, Tosa Y, Valent B, Wang Z, Xu J-R (2016a) Generic names in Magnaporthales. IMA Fungus 7:155-159

Zhang HF, Zheng XB, Zhang ZG (2016b) The Magnaporthe grisea species complex and plant pathogenesis. Mol Plant Pathol 17:796-804 